\title{
Co-Creation in the Game Industry: A Case Study in a Brazilian Developer
}

\author{
Marcos Vinicius Cardoso', Huoston Rodrigues Batista², Ernani Marques da Silva², \\ Marcos Antonio Gaspar², Ivanir Costa ${ }^{2}$, Fábio Luís Falchi de Magalhães ${ }^{2}$ \\ ${ }^{1}$ Universidade Anhembi Morumbi, São Paulo, Brazil \\ ${ }^{2}$ Graduate Program in Informatics and Knowledge Management, Universidade Nove de Julho (UNINOVE), São Paulo, Brazil \\ Email: mvcardoso@gmail.com, huostonrodrigues@gmail.com, ernani@athem.net.br, marcos.antonio@uni9.pro.br, \\ ivanirc@uni9.pro.br, f.magalhaes@uni9.pro.br
}

How to cite this paper: Cardoso, M.V., Batista, H.R., da Silva, E.M., Gaspar, M.A., Costa, I. and de Magalhães, F.L.F. (2018) Co-Creation in the Game Industry: A Case Study in a Brazilian Developer. Social Networking, 7, 63-78.

https://doi.org/10.4236/sn.2018.71005

Received: November 25, 2017

Accepted: January 12, 2018

Published: January 15, 2018

Copyright (c) 2018 by authors and Scientific Research Publishing Inc. This work is licensed under the Creative Commons Attribution International License (CC BY 4.0).

http://creativecommons.org/licenses/by/4.0/

\begin{abstract}
The objective of this work is to understand how the process of co-creation occurs within the creative industry of video games. For this, concepts of the creative industry, co-creation, information and communication technologies (ICTs) and innovation were studied. Since this is an exploratory and qualitative research, a single case study was chosen as a method. The analysis was done in a Brazilian company that develops games for mobile devices. The results show that the consumer (gamer) participates in value creation in the company's products, mainly in the initial production stages. In the later phases, after the launch and other steps of the life cycle, although there is a relationship with the users, the joint creation of value is little explored by the organization. Also, it was verified that the co-creation process is supported by different information and communication tools, which provide agility to the process.
\end{abstract}

\section{Keywords}

Co-Creation, Empirical Studies, Gaming Communities, Information and Communication Technologies, Innovation

\section{Introduction}

The creative industry of video games has proven to be one of the most important industries within the entertainment industry along with filmmaking [1] [2] [3]. This importance is due both to the growth of corporate revenues and to the technological and innovative emphasis on organizations.

The technological innovations that have occurred in recent years have allowed 
the development of video games to migrate from large traditional countries to several new markets [1]. Among these innovations, we can mention the growth of mobile devices and the increasing access to the internet [4] [5]. The reduction of production costs and access new customers via new platforms are a direct result of these innovations.

Brazilian developers could, in this new competitive scenario, offer their products to markets that previously could not be accessed. This previous limitation was due to the high investment required to provide the products and the difficulty of knowing and competing with already established giant companies.

Another characteristic brought by the innovations in the industry is the increasing participation of consumers (gamers) in the process of product development. This engagement can be understood as a co-creation of value [6] [7] [8] [9]. In this way, the paradigm that the company creates value and sells it to its consumers ceases to exist, passing the consumer to be an active participant in the creation of value for the organizations [7].

It is not common in the game development literature to use the concept of co-creation, and even managers of developers do not seem to know the idea. In Brazil, concepts such as co-creation and open innovation are not familiar within the games industry [10] [11] [12], which probably explains the absence of academic production on such concepts.

In this context, this work is developed. Therefore, the objective of this study is to understand how the process of co-creation occurs within the creative industry of video games. Also, understand the role of Information and Communication Technologies (ICTs) tools in co-creation process. Because it is a qualitative and exploratory research, the chosen method was the single case study, having as object a Brazilian game developer company with products launched internationally.

The results show that the concept of co-creation is unknown to managers. However, other constructs used and already established in the industry such as consumer development [13] [14], seem to approximate the concept of co-creation. What is evident is that the consumer participates in the development and changes made to products making it clear that there is a co-creation of value, although this is not explicitly planned by the organization. The lack of planning on how to create value together with consumers limits the benefits of co-creation.

This paper is divided into five parts. In addition to this introduction, the literature review focuses on Innovation, Information and Communication Technologies (ICTs) and Co-creation. After that we discuss the methodology followed the presentation of results. Finally, we present the final considerations, which also point the limitations and proposals for future studies on the theme.

\section{Literature Review}

In this section, we present the concepts that will be used in this work, especially Innovation, Information and Communication Technologies, and Co-creation. 


\subsection{Innovation}

The concept of innovation consists of an idea, practice or the material good of relevant application [15] and constitutes a fundamental factor for competitiveness and growth [16].

Innovation is also present in the social impact of new communication and information technologies, in the new receptor, now producing and interacting, in cognitive processes, languages, aesthetics and even in modern methodological and theoretical approaches to communication. That's because innovation is a social, symbolic and technological phenomenon, present in all mediatic contemporary society and can pervade the entire field of Communication [17].

It can be seen that co-creation, ICTs, and innovation are remarkably linked to one another, forming a crucial tripod for the industry as a whole. This is especially true in the video game industry, which aims to launch new products with characteristics and features that, in addition to attracting and engaging the consumer in the product, can also contribute to the creation of new products. The quest to differentiate themselves from competitors and attractiveness are crucial for the industry in question.

There is a definite relationship between the degree of competitiveness and the ability with which they create value for their customers [18]. Thanks to the popularization of the Internet, which has enabled the emergence of numerous communication technologies in real time, the client is more informed and educated, more selective and demanding and has a higher capacity for choice. This new consumer demands a greater generation of value by companies [19].

\subsection{Information and Communication Technologies}

As the advance of information and communication technologies (ICTs), many creative sectors were modified during the 90's with the advent of the Internet in a more exploratory and commercial way, making it possible to shorten the distance between organizations, among individuals and between individuals and Organizations. We can take as an example the music industry in which piracy and the distribution of music via Internet caused significant damages the profits of the distributors. The video game industry was able to identify that the handsets and tablets became a new platform for gaming and also for digital distribution, allowing the reduction of the costs with stocks, physical material and even of their distribution [20].

And it is precisely the creative industries that take the most significant advantage in the use of technology devices, especially in the area of information and communication technologies [21].

Among the ICTs is the internet, mobile telephony and also data transfer technologies that impact organizations in at least two fundamental aspects: a) generate changes in the industries in which companies operate [20] while creating needs for new ways of relating to consumers; b) impact on the way and the internal structure of the organizations, causing changes in the management 
models and the technical structure of the company [22].

In this way, ICTs help in a way that is either a creator of demand for new products, services or businesses, also new ways in which they can relate to consumers, as well as being tools that facilitate the process of adapting the company to such new demands.

When studying the literature on ICT, the most common is to find results related to the effect generated by the adoption of ICTs. Thus, studies show commonly that organizations use ICT for better results or benefits concerning cost control, profitability and efficiency [23] [24] [25].

These results generate motivations for organizations. Often these motivations are created by governments themselves, to use ICT as a form of innovation. In some cases, ICTs are tools for creating innovation, and in others, ICTs are the innovation itself.

\subsection{Co-Creation}

The current variety of products, as well as the possibility of finding several different characteristics of the same product, does not always result in the best consumer experiences. And it is precisely in this scenario that certain organizations take ownership of the idea of co-creation of value, that is, the participation of the final customer during the productive process, in a way that allows innovating in the business model, generating an additional value to its offer and then differentiate themselves from other companies [26].

The co-creation with customers becomes a new source of competence of business strategies [27]. Reference [18] proposes a conceptual model (Figure 1) for co-creation of value that contemplates the primary processes to manage the co-creation and examine several implications for the development of products and services, develop the relationship with the customer cross-functional alignment and knowledge management.

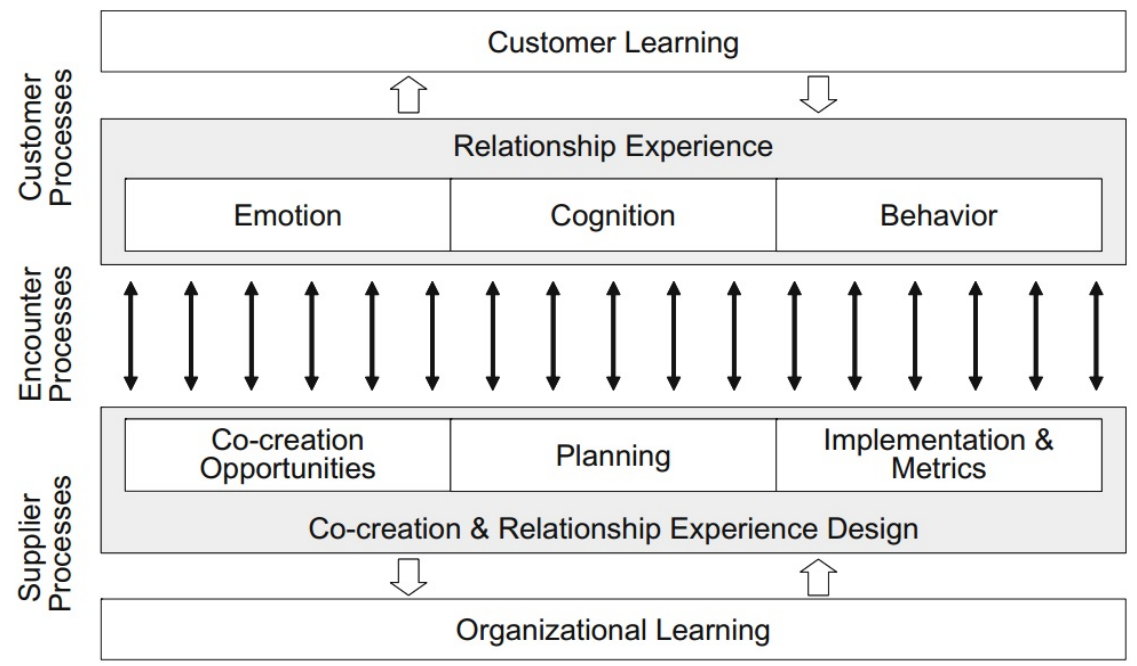

Source: [[18], p. 86].

Figure 1. A conceptual model for co-creation of value. 
The co-creation, at present, has no specific exclusivity in one segment or another [28]. However, information and communication technology (ICT) products have more often been used in co-creation. This has to do with the various possibilities that ICTs have generated in recent years, the ease of entry in the market related to ICTs and the ease of communication and exchange of experiences where tacit knowledge has often been shared and allowing them to an existence of openings for co-creation.

Co-creation in games was the subject of a study by [29] where the author concluded that the level of customization, content, interactivity and complementarity influence the level of acceptance of the players more quickly. For the author, this process of co-creating, through interactivity, the possibility of content customization, awakens a pleasant and effective interaction between the player and the system within these virtual communities.

However, the definition of an organizational strategy based on or with elements of co-creation needs to be aided by the knowledge of the existing community; The typology of [30], explained below, can help identify the main types of community users and their connections with the company. They can also help in the definition of guidelines for co-creation of value for the company and to answer strategic questions such as: Are organizational strategies aligned with the community? Are there interfaces that are consistent with the community? Are there community guidelines for game creation? Are there specialized works in the community that can contribute to co-creation?

In this typology, we have the cross-referencing of vertical orientations (degree of specialization of the work done by the community) and horizontal (community focused on game and content and the community focused on the technologies involved in the game). Table 1 describes each segmentation of the typology in which one can classify the community and then elaborate the most appropriate strategy according to the organizational strategy aligned with the needs of the respective communities.

The first products launched were the mostly result of finished product delivered to the consumer and nowadays they appear more and more through some process of co-creation thanks to the contributions of the players they were able to evolve the game progressively [31].

We found in literature studies of new software products ideas coming from online communities, by the focus of innovation researchers [32], and by marketing researchers through an emphasis on the description of consumption of physical and virtual products [33]. Reference [30] reports that a particular gap exists in these studies regarding the nature of the relationship between the company and the community. In their opinion, a) the domain of knowledge and cognitive activities that the company should delegate to user communities; b) After the delegation of these domains, little research answers the question of how companies can seize or direct communities to make this effort lucrative.

The participation of communities usually begins in game development well before it comes to a beta test that is already, at this stage, available to the market. 
Table 1. Types of communities in the video game industry.

\begin{tabular}{|c|c|c|}
\hline Type & Sub-type & Description \\
\hline \multirow[t]{4}{*}{ Player } & Tool developer & $\begin{array}{l}\text { - The company tries to align itself with the goals of the community } \\
\text { - The company tries to attract users attention }\end{array}$ \\
\hline & Content builder & $\begin{array}{l}\text { - The company mainly tries to assimilate information from the community } \\
\text { - The company tries to develop the product for a community }\end{array}$ \\
\hline & Organizer & $\begin{array}{l}\text { - The company mainly tries to assimilate information from the community } \\
\text { - The company tries to develop the product for a community }\end{array}$ \\
\hline & Open player & $\begin{array}{l}\text { - The company tries to attract the attention of users } \\
\text { - Developed without the user community }\end{array}$ \\
\hline \multirow[t]{4}{*}{ Tester } & Web games producer & $\begin{array}{l}\text { - The company tries to align their goals with communities } \\
\text { - The company tries to develop the game with the community }\end{array}$ \\
\hline & Market thermometer & $\begin{array}{l}\text { - The company tries to align with the goals of the communities } \\
\text { - The company tries to develop the product for a community }\end{array}$ \\
\hline & Creative tester & $\begin{array}{l}\text { - The company tries, mainly, to assimilate the information of the communities } \\
\text { - The company tries to develop the product for a community }\end{array}$ \\
\hline & Technology/beta tester & $\begin{array}{l}\text { - The company tries to catch the attention of users } \\
\text { - The game is developed without the community }\end{array}$ \\
\hline Developer & & - The company tries to take advantage of the whole community production \\
\hline
\end{tabular}

Source: Adapted from [30]. 


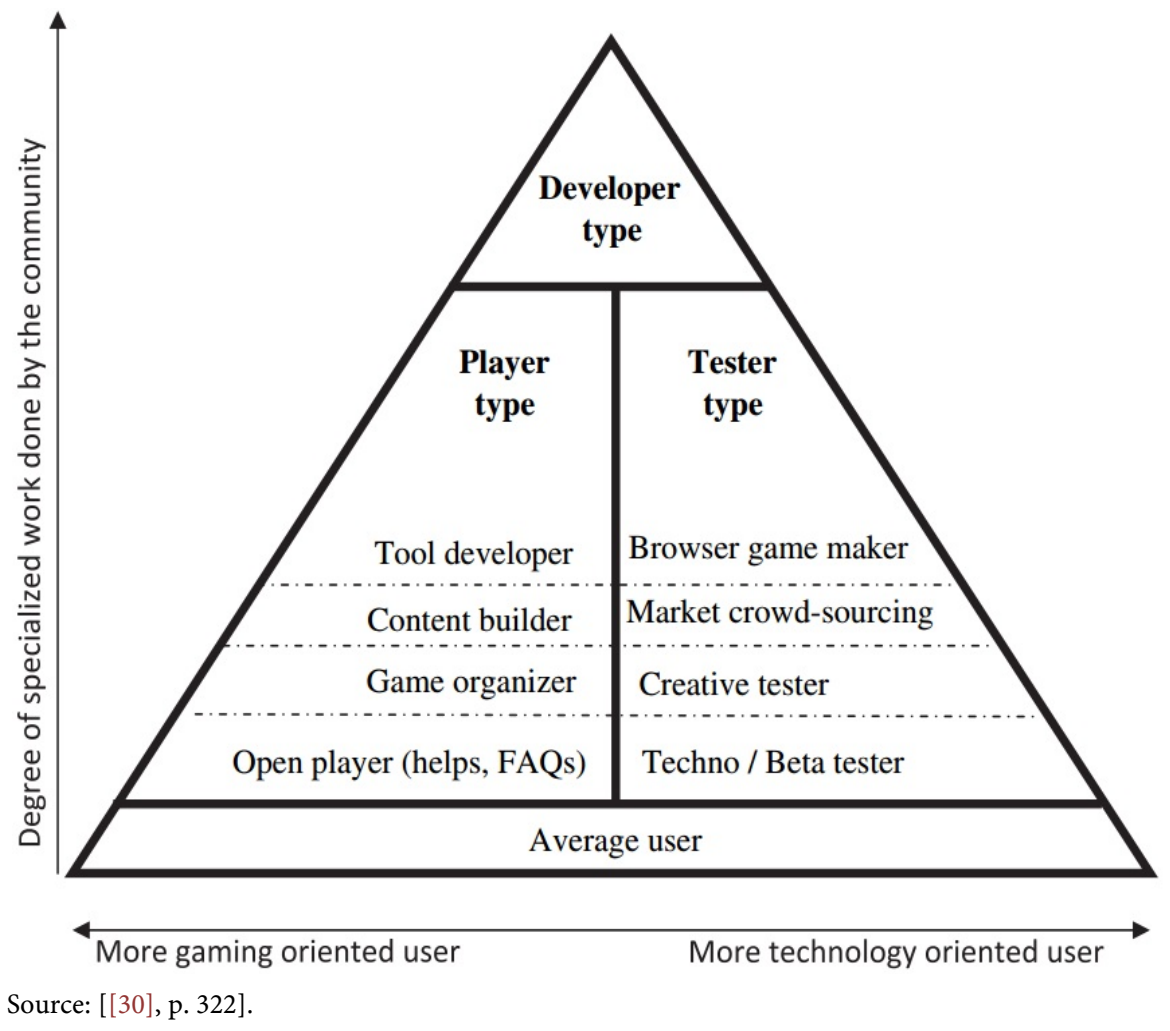

Figure 2. Types of communities in the video game industry.

findings in a larger group of entities [38]. Oktagon was chosen for the case study for being one of the five largest Brazilian game developer companies according to [39]. The company had already launched a successful mobile platform game for IOS and Android and received investment from a venture capital fund. With this investment, the company could improve its products and give more attention to the co-creation. Another relevant factor in the choice is that during the experimentation of the games of Brazilian companies it was clear the interaction of Oktagon with its consumers and the relevance of this interaction to upgrade their product.

The application of the case study method requires the implementation of some protocols that guarantee the scientific status of the research. Perhaps the primary protocol is in data collection. Thus, it is suggested that the data collection be done in several sources that allow the triangulation of information [37]. In the following case presented the collection occurred at various times. One of the authors of the paper played one of the company's products, collecting data during the experiment. This data collection occurred from October 2013 to March 2015. The product Ant's and Armys was used in the mobile platform iOS using an Ipad X. The researcher collected screenshots of dialogues between players (consumers) and representatives of the company. We sought discussions that could indicate the company's receptivity to innovations suggested by consumers, as well as the process of implementing these innovations, whether in the game mechanics or in the events promoted by the company or by the players 
within the game.

We also interviewed one of the owners of the company responsible for business management, with knowledge (Chief Executive Officer) and interface with the development areas. This interview took place in two meetings. The first happened in the Rio de Janeiro's office in November 2014, where information about the company was collected and we received access to strategic planning documents. Through open questions we could better understand the company's history and future plans. This meeting lasted about an hour and a half. The second part of the interview took place in Londrina's office in July 2015. Here the data collection took place through a semi-structured interview script focused on the issues that emerged from the literature studied.

In addition, other two owners were interviewed, the Chief Technology Officer and the Art Director using the same semi-structured script applied to the CEO. These interviews were recorded and later transcribed to facilitate future analyses.

Finally, users who participated as testers at some post-launch time were contacted or had their activities in the game chats stored for review. The collection of chats were transcribed for the analysis phase, in total the conversations of 20 different users were analyzed. The interviews occurred with five users via Skype and followed a semi-structured interview script based on the literature studied. The choice of these five users was due to the type of interactions observed in the chat analysis. We sought users who were highly involved in the beta test phase of game improvements, in-game event creation and acting as helpers to other players during their in-game performance.

The analysis of the results tried to cross the information of the several sources to validate or even to oppose the vision of the organization, with its practical implementation. On the other hand, understanding how consumers participated in the various stages of value creation in product development.

\section{Results}

\subsection{The Company and Its Products}

Oktagon was officially founded in 2009, but in its origin, it was called Calibre, a company organized in 2002 in an incubator at the Federal University of Cornélio Procópio, Brazil. Students of the institution formed the group and it was never formalized. During the early years, Calibre focused its efforts on providing services rather than creating its own Intellectual Properties. In THIS way, the company was able to pay the bills providing services to several corporations including in Europe and the United States.

The money accumulated with the provision of service, however, was insufficient to make the leap and allow Oktagon, a company created for its own projects, to develop its Intellectual Properties (IP). In 2012, with an investor input, the owners resolved to give full focus on the development of their products. While Calibre worked with about 25 employees, Oktagon had a much leaner and more mature structure with 13 people. Thus, they focused on the mobile plat- 
forms where the company saw more opportunities in the market working with a more experienced team and producing high-quality games.

Even though it is a lean company, it operates in two offices in Londrina and Rio de Janeiro. The investment in Rio de Janeiro happened because of the investor who was based in that city. The advantage of the proximity with the investor, however, did not compensate, due to the high costs of the city that hindered the maintenance of the employees. At the moment, the Rio team that had seven people was reduced, and the most substantial investment is now in the city of Londrina.

Concerning the products, the company had two current titles: Armies \& Anties and Dungeon Battles.

\subsection{The Co-Creation in Oktagon}

Oktagon uses in its development strategy the Co-production where there is no contract to carry out the work but rather a partnership with other companies. Thus, the partner does not fit into an "outsourcing" but rather as a co-producer who can offer for the production of the product something that the company could not do alone. Co-production also occurs at the moment where the partner allows a reduction in production time even though the work of both parties overlaps. Often companies seek these partnerships to allocate teams that are idle within the development team. This allows innovative new projects to emerge while the day-to-day business is not affected. However, the point that most characterizes the partnership as co-production is that both companies share the risk of the new product.

In this case, although the activity is not included in the concept of co-creation presented, it seems evident that in the case of co-production, both companies help create value. This creation of value, however, occurs only in the supply of the products, that is, it does not reach the level of involvement with the consumer.

\subsection{Co-Creation versus Consumer Development}

In its relationship with the consumer, Oktagon uses the concept of Consumer Development [13] adapted since it is focused on software. This concept assumes that companies should no longer develop their products and only present them to their customers in the test phase. The goal is to fail as soon as possible [14]. Thus, the company launches a Minimum Viable Product, and this was adjusted from the flaws arising from the use made by consumers. In this way, organizations can better understand the market, since the adjustments cause the product to be developed with the direct involvement of consumers.

Oktagon started copying models of companies that already used the concept adapting the same to games. The idea is to test the game before making the game. Thus, using the end user to develop the product that best fits the expectations of these. 
For this, the company started using what it called "vertical-slice". At this stage, the company seeks to test the prototype before starting production effectively. These prototypes can be quite simple without color or without the depth of design.

When the tested prototype already has images, and is closer to the final product the company does beta tests where players participate by testing the gameplay, bugs, and product features. Finally, users from countries where they are not expected to have a large demand participate in the soft launch. Often the products stay for four to five months at this stage, receiving feedback on game balancing and thoroughly testing until the release.

These were the steps pointed out by the company with greater participation of the consumers. It was verified that there is no prior reading of co-creation opportunities, as we will see in the organization's strategies.

\subsection{Strategy and Co-Creation}

From 2012, when the company received investments, all the strategic planning of the company started to be done based on the updated business plan. The company has a board of directors that reviews the business plan every six months. In these reviews, the strategies relating to products may be changed. As the market is very dynamic, the organization needs these periodic reviews for business alignment. There are monthly board meetings that analyze the company's Key Performance Indicator. At these meetings attended by the director of the company, a representative of the investment fund and invited expert advisors. The minutes of these meetings are formalized and kept for consultation and sent to investors.

Co-creation was not mentioned in the planning because the company did not use the term. Thus, it was not possible to verify if at any stage of the organization's strategic planning its concepts impact the long-term decisions. However, it was perceived as seen in the previous topic that in the most tactical context Consumer Development is used, whose principles are tangent to that of Co-creation.

\subsection{ICT and Co-Creation}

Interviewee 2 (Chief Technology Officer) stated that information and communication technology tools play an important role supporting the co-creation process. In order to enable the co-creation process, the interviewees reported the usage of various ICT tools used by the company in various processes. For content creation, the company employs tools such as Wiki, Mentis software, and data mining tools such as Tableau and PowerBI.

To manage and control content, the company uses tools such as Gliff, Github, Basecamp and Trello. As the main communication and collaboration technologies, the company uses Skype, Hangout and Slack, as well as routine messaging tools such as Gmail and corporate social networks and intranets. 
In addition, the company also employs specific technologies for employee training, and computational intelligence tools, such as expert systems and decision-making. During the interviews, it was verified that some of the tools cited by the interviewees were categorized in more than one application. An example of this is the Wiki tool and Mantis.

\subsection{Gamers and Co-Creation on Oktagon}

Concerning the consumers (gamers) of the game analyzed, Armies \& Ants, it is clear their involvement in the various phases of relationship between them and the company. Consumers generally participated in improvements tests with the game already launched and in the suggestion of new features. The testers played earlier versions of the product for bug checking and also for balancing the product. This usage was shown to be planned by the company. No consumers interviewed had participated in the prototype phase. We also found players who helped other user that had in-game doubts and organized events within the game.

Following the typology of [30], it can be stated that Oktagon consumers can be considered as testers, "technology testers/beta" and "creative testers", and when players, "open player" and "game organizer". In both cases, the consumers are at the bottom of the pyramid.

The technology testers are those that the company uses in the vertical slice, giving basic support to the technical development of the product, while beta testers participate in a phase closer to launch or post-launch. In the latter case, the game is already an evolved version or even a future update of the product. Creative testers give new ideas for improvements by trying to add to their tests their perceptions about users' needs and not just the viability or not of the suggested innovations/improvements.

There is an emphasis on the use of technology testers at the beginning of the development process, the beta testers during the final development process, in the soft launch and also in the first year of the product, while the creative tester appears in the post-release and during the life of the product.

Consumers considered open players actively participate in the discussion forums, helping to question other players and encouraging other players to participate in battles. These players are usually the most active and become references to the rest. According to the interviewee 1 (Chief Executive Officer), the company employs the use of community managers who communicate directly with the players and report improvements, as well as register the users' requests. Oktagon created incentives for these players to continue to perform this role in Armies \& Ants by giving a special veteran tag to these players. The company took advantage of his experience in China with another game, Dugeon Battle as an incentive to bring this innovation. In the Chinese market, there is the role of the tutor player. The role of this player is to help answer questions and assist new players. This figure in the game environment is seen in China as more relia- 
ble than one of the developers. Thus, the company has taken over the development of this new function.

Players organizers of the game have also been found. Clan leaders play this role as they organize their teams into battles and at the same time encourage/ challenge other leaders in the organization of wars. In some moments, players were found organizing mini tournaments within the clans themselves, also playing this role.

It was evident in the analysis of the company that there is a great participation of the consumers in several phases. When analyzing the participation of the consumer within the model proposed by [18], it is clear that the relationship experiences within the client processes appear.

Users have a very strong emotional relationship, generated by interaction with the game and with other players. This occurs not only with players from the same country but also with international groups. Discussions through the public chat, creation of Whats App groups and other behaviors show a link that helps to engage and therefore participation in the co-creation. Interviewee 1 states that the company seeks to decrease distance with the player through in-game communication tools, such as a space for exchanging direct online messages between the player and the company.

On the cognitive side, there is also an incentive to involve consumers. The use of logic and the receipt of prizes make the consumer increase participation and thus have a better knowledge of the product, or even learn about the innovations that will come before implementation. This generates a desire to participate in the betas that may be the basis for the future of the product. As an example of the company's effort to communicate more effectively with players, respondent 2 states that in games produced by the company, there is a feature known as welcome screen, a screen within the platform that gathers information about the game universe updated via server.

It became clear that consumers are co-creators of value in the development of company products. That demands of the company a greater strategic focus on the creation of opportunities of co-creation as well as of process management. The following is the final considerations on the work.

\section{Final Considerations}

The role of the creative video game industry in the development of innovations and the application of innovations is increasingly discussed and exalted. In this sense, ICTs allowed this industry to move away from traditional markets, providing an excellent opening of markets for smaller and less capital-intensive companies; also, enabled a more significant interaction with the consumer to pass from a simple final product customer buyer to a co-creator on several levels.

This work aimed to identify how the concept of co-creation is known and used by a video game developer in Brazil. The findings show that the concept is not known, but the industry uses concepts such as Consumer Development that 
has several aspects in common with Co-creation. As the concept is not widespread the supplier process steps (developer) are not followed, not allowing the organization to have the full benefits of co-creation.

In this way, the search for opportunities of co-creation does not occur, not occurring the planning and consequently, implementation and measurement. The result is that the company uses consumers more intensely only in the early stages of the project. After this intense relationship, the company becomes reactive.

On the consumer side, there was a significant motivation to participate in the various stages of development and the operationalization of the product. Here it is important to note that in multiplayer games players' attitudes and behavior influence both their participation in the game and the experience of other users. For this reason, developers who achieve a long-term relationship with the players will be able to create more value for their products.

As a limitation of the study, it can be indicated the impossibility of generalization of the results found for other companies in the sector. The case study method suggests some directions that must be proven by means of quantitative studies. Another limitation was the choice of a company operating only in the mobile market. Companies in other segments may have different characteristics that make possible new perceptions.

Considering that this research is dedicated to the study concerning the application of concepts not widely used in the Brazilian gaming industry, while such concepts are widely applied successfully in other industries, it can be said that this work contributes towards revealing a field study that demands more research and deepening. One possibility for future research is to study the concept of co-creation combined with the open innovation concept in the Brazilian market for games and even the financial impact that the adoption of these concepts can bring to companies that adopt them.

Regarding future studies, it is suggested a multiple case study with at least three companies raising other points or perceptions of development companies. This study should contain companies operating on different platforms and preferably with different maturity stages. In addition to this study, a deepening of the concepts of Consumer Development and Co-creation would make possible a better understanding of their interfaces and even the formulation of a new model dedicated to the creative industry of video games.

\section{References}

[1] Cardoso, M.V. (2013) A proposição de um modelo de análise para a indústria criativa de videogames no Brasil. Ph.D. Thesys, Universidade de São Paulo, Brazil.

[2] Dymek, M. (2012) Video Games: A Subcultural Industry. In: Zackariasson, P. and Wilson, T.L., Eds., The Video Game Industry: Formation, Present State, Future, Routledge, New York, 34-56.

[3] Shen W. and Altinkemer, K. (2008) A Multigeneration Diffusion Model for IT-Intensive Game Consoles. Journal of the Association for Information Systems, $\mathbf{9}$ 
442-461.

[4] Wang, J. (2011) Meet the Entrepreneurs behind the Booming Business of Games. Entrepreneur. https://www.entrepreneur.com/article/219641

[5] Landsman, V. and Stremersch, S. (2011) Multihoming in Two-Sided Markets: An Empirical Inquiry in the Video Game Console Industry. Journal of Marketing, 75, 39-54. https://doi.org/10.1509/jm.09.0199

[6] Prahalad, C.K. and Ramaswamy, V. (2013) The Future of Competition: Co-Creating Unique Value with Customers. Harvard Business Press, Brighton, MA.

[7] Gidhagen, M., Ridell, O.P. and Sörhammar, D. (2011) The Orchestrating Firm: Value Creation in the Video Game Industry. Managing Service Quality. An International Journal, 21, 392-409. https://doi.org/10.1108/09604521111146261

[8] Svensson, G. and Grönroos, C. (2008) Service Logic Revisited: Who Creates Value? And Who Co-Creates? European Business Review, 20, 298-314. https://doi.org/10.1108/09555340810886585

[9] Vargo, S.L. and Lusch, R.F. (2008) Service-Dominant Logic: Continuing the Evolution. Journal of the Academy of marketing Science, 36, 1-10. https://doi.org/10.1007/s11747-007-0069-6

[10] Panizzon, M., Roldan, L.B., Menegotto, M.A. and Dorion, E.C.H. (2013) Novas mudanças em Design Organizacional para fomentar Co-Criação Dinâmica e Inovação: Um modelo baseado em games multiplayer online. SBC XII Proceedings of SBGames, São Paulo, 16-18 October 2013, 28-37.

[11] Fleury, A., Sakuda, L.O. and Cordeiro, J.H.D.O. (2014) I Censo da Indústria Brasileira de Jogos Digitais. NPGT-USP e BNDES, São Paulo.

[12] Mello, G.A.T.D. and Zendron, P. (2015) Como a indústria brasileira de jogos digitais pode passar de fase. BNDES Setorial 42, Rio de Janeiro, 337-382.

[13] Blank, S. and Dorf, B. (2012) The Startup Owner's Manual: The Step-By-Step Guide for Building a Great Company. K \& S Ranch, Pescadero, CA.

[14] Blank, S. (2007) The Four Steps to the Epiphany: Successful Strategies for Products that Win. Lulu Enterprises Incorporated, Raleigh, NC.

[15] Rogers, E.M. (2010) Diffusion of Innovations. Simon and Schuster, New York.

[16] Storz, C., Riboldazzi, F. and John, M. (2015) Mobility and Innovation: A CrossCountry Comparison in the Video Games Industry. Research Policy, 44, 121-137. https://doi.org/10.1016/j.respol.2014.07.015

[17] Rossetti, R. (2013) Categorias de inovação para os estudos em Comunicação. Comunicação \& Inovação, 14, 63-72. https://doi.org/10.13037/ci.vol14n27.2262

[18] Payne, A.F., Storbacka, K. and Frow, P. (2008) Managing the Co-Creation of Value. Journal of the Academy of Marketing Science, 36, 83-96. https://doi.org/10.1007/s11747-007-0070-0

[19] Vega-Vazquez, M., Ángeles Revilla-Camacho, M. and Cossío-Silva, F.J. (2013) The Value Co-Creation Process as a Determinant of Customer Satisfaction. Management Decision, 51, 1945-1953. https://doi.org/10.1108/MD-04-2013-0227

[20] UNCTAD (2010) Creative Economy: A Feasible Development Option.

[21] Müller, K., Rammer, C. and Trüby, J. (2009) The Role of Creative Industries in Industrial Innovation. Innovation, 11, 148-168. https://doi.org/10.5172/impp.11.2.148

[22] Prahalad, C.K. and Krishnan, M.S. (2008) The New Age of Innovation: Driving Cocreated Value through Global Networks. McGraw-Hill Education, New York.

[23] Qureshi, S. and York, A.S. (2008) Information Technology Adoption by Small 
Businesses in Minority and Ethnic Communities. Proceedings of the 41 st Annual Hawaii International Conference on System Sciences, Waikoloa, 7-10 January 2008, 1-10. https://doi.org/10.1109/HICSS.2008.204

[24] Ho, S.-C., Kauffman, R.J. and Liang, T.-P. (2008) A Growth-Theoretic Empirical Analysis of Simultaneity in Cross-National e-Commerce Development. Proceedings of the 41 st Annual Hawaii International Conference on System Sciences, Waikoloa, 7-10 January 2008, 410. https://doi.org/10.1109/HICSS.2008.22

[25] Bharadwaj, A.S. (2000) A Resource-Based Perspective on Information Technology Capability and Firm Performance: An Empirical Investigation. MIS Quarterly, 24, 169-196. https://doi.org/10.2307/3250983

[26] Zmoginski, A.S., Kwak, A.I.B., de Moraes Canabarra, C., de Freitas Bertolino, D., Ynonye, F.Y. and Ades, C. (2010) Co-criação de valor: Inovação no modelo de negócio obtendo vantagem competitiva. Revista Jovens Empreendedores. Mackenzie, Brasil, 6, 46-65.

[27] Prahalad, C.K. and Ramaswamy, V. (2004) Co-Creation Experiences: The Next Practice in Value Creation. Journal of Interactive Marketing, 18, 5-14. https://doi.org/10.1002/dir.20015

[28] Lang, K., Shang, R. and Vragov, R. (2015) Consumer Co-Creation of Digital Culture Products: Business Threat or New Opportunity? Journal of the Association for Information Systems, 16, 766-798.

[29] Yeh, S.Y. (2010) Involving Consumers in Product Design through Collaboration: The Case of Online Role-Playing Games. Cyberpsychology, Behavior, and Social Networking, 13, 601-610. https://doi.org/10.1089/cyber.2009.0323

[30] Burger-Helmchen, T. and Cohendet, P. (2011) User Communities and Social Software in the Video Game Industry. Long Range Planning, 44, 317-343. https://doi.org/10.1016/j.lrp.2011.09.003

[31] Cadin, L. and Guérin, F. (2006) What Can We Learn from the Video Games Industry? European Management Journal, 24, 248-255. https://doi.org/10.1016/j.emj.2006.05.001

[32] Bilgram, V., Brem, A. and Voigt, K.-I. (2008) User-Centric Innovations in New Product Development-Systematic Identification of Lead Users Harnessing Interactive and Collaborative Online-Tools. International Journal of Innovation Management, 12, 419-458. https://doi.org/10.1142/S1363919608002096

[33] Algesheimer, R., Dholakia, U.M. and Herrmann, A. (2005) The Social Influence of Brand Community: Evidence from European Car Clubs. Journal of Marketing, 69, 19-34. https://doi.org/10.1509/jmkg.69.3.19.66363

[34] Burger-Helmchen, T. and Guittard, C. (2008) Are Users the Next Entrepreneurs? A Case Study on the Video Game Industry. International Journal Entrepreneurship Education, 6, 57-64. https://doi.org/10.2139/ssrn.1146531

[35] Llerena, P., Burger-Helmchen, T. and Cohendet, P. (2009) Division of Labor and Division of Knowledge: A Case Study of Innovation in the Video Game Industry. In: Cantner, U., Gaffard, J.-L. and Nesta, L., Eds., Schumpeterian Perspectives on Innovation, Competition and Growth, Springer, Berlin Heidelberg, 315-333. https://doi.org/10.1007/978-3-540-93777-7_18

[36] Davidovici-Nora, M. (2009) The Dynamics of Co-Creation in the Video Game Industry: The Case of World of Warcraft. Communications and Strategies, 73, 43-66.

[37] Yin, R.K. (2015) Estudo de Caso. 5th Edition, Planejamento e Métodos, Bookman Editora. 
[38] Eisenhart, M. (2009) Generalization from Qualitative Inquiry. In: Ercikan, K. and Roth, W.M., Eds., Generalizing from Educational Research: Beyond Qualitative and Quantitative Polarization, Routledge, New York, 51-66.

[39] ABRAGAMES Associação Brasileira dos Desenvolvedores de Jogos Digitais (2017) O que estamos fazendo. ABRAGAMES, São Paulo. http://www.abragames.org/o-que-estamos-fazendo 